\title{
O FILME CURTO NA DEMOCRACIA BRASILEIRA
}

THE SHORT FILM IN BRAZILIAN DEMOCRACY

\author{
Paulo Maia \\ ORCID 0000-0001-8082-1770
}

Universidade Federal do Rio de Janeiro

Rio de Janeiro, Brasil

\section{Resumo}

Trata-se de um balanço do cinema independente no período de construção da democracia no Brasil, 1985 a 2016. Um recorte temporal com filmes que retratam um projeto democrático de emergência de identidades apagadas no cinema nacional. O lugar do negro, das mulheres, dos pobres assumiu um estatuto tensionado nesse novo contexto. O dia em que Dorival encarou a guarda, de Jorge Furtado (1986), por exemplo, narra a estratégia e perspicácia de um detento negro para tomar uma ducha, depois de dez dias preso na solitária por ordem ninguém sabe de quem. Kbela, Yasmim Thainá (2015), por outro lado, é um filme de mulher negra e de origem humilde. A narrativa mostra a transformação de cinco mulheres que superam o preconceito racial descobrindo a própria identidade, a cor, a cultura, a ancestralidade. Entre os dois filmes, é possível identificar uma trajetória que transforma a figuração da liberdade de ação.

Palavras-chave: Cinema independente, Curta-metragens, Novas visibilidades, Período democrático

\section{Abstract}

This paper presents a review of independent cinema in the period of democracy building in Brazil from 1985 to 2016 , a time span with films that portray a democratic project of emergence of erased identities in national cinema. The place occupied by black people, women and the poor assumed a tense status in this new context. The Day Dorival Faced the Guard by Jorge Furtado (1986), for example, chronicles the strategic and shrewd thinking of a black inmate in order to be able to take a shower after ten days in solitary confinement by order of no one knows who. Kbela by Yasmim Thainá (2015), on the other hand, is a black woman's film

\section{Résumé}

C'est un bilan du cinéma indépendant dans la période de construction de la démocratie au Brésil, de 1985 à 2016. Une coupe temporelle avec des films qui dépeignent un projet démocratique d'émergence d'identités effacées dans le cinéma national. La place des noirs, des femmes, des pauvres a pris un statut tendu dans ce nouveau contexte. Le jour où Dorival a affronté le garde, par Jorge Furtado (1986), par exemple, relate la stratégie et la perspicacité d'un détenu noir de prendre une douche, après dix jours d'isolement cellulaire sur ordre dont personne ne sait à qui. Kbela, Yasmim Thainá (2015), quant à lui, est un film de femme noire d'origine modeste. Le récit 
of humble origin. The narrative shows the transformation of five women who overcome racial prejudice by discovering their own identity, color, culture, ancestry. In the two films it is possible to identify a trajectory that transforms the figuration of freedom of action.

Keywords: Independent cinema, Short films, New visibilities, Democratic period montre la transformation de cinq femmes qui surmontent les préjugés raciaux en découvrant leur propre identité, couleur, culture, ascendance. Entre les deux films, il est possible d'identifier une trajectoire qui transforme la figuration de la liberté d'action.

Mots-clés: Cinéma indépendant, Courts métrages, Nouvelles visibilités, Période démocratique

"A verdadeira imagem do passado perpassa, veloz" (BENJAMIN, 1940, p. 224). Para Walter Benjamin, o agora definiria a história, como um flash. Se a história da vida orgânica na Terra ocupasse as últimas 24 horas, a humanidade civilizada ocuparia algo como um quinto do último segundo. Através desta perspectiva, seria no relance que devíamos ler as coordenadas dos processos históricos. Ao historiador caberia, assim, a tarefa de identificar o curso de um feixe determinado de luz no espaço; ao artista caberia a tarefa de uma iluminação profana, um gesto contrário, um desvio da luz enformada na tradição. $\mathrm{O}$ agora reconhecível (das jetzt der erkennbarkeit) seria, para Benjamin, o limiar entre o ritmo e a resistência. Analiso, neste artigo, dois filmes brasileiros curtos e independentes que, distantes 30 anos um do outro, permitem perceber algumas coordenadas no balanço histórico entre o fim da ditadura no Brasil 1985 e o golpe parlamentar de 2015.

Neste texto, apresento as questôes abordadas na construção da curadoria de uma mostra construída em cinedebates com estudantes e professores universitários e do ciclo básico. Criado por iniciativa de universitários, o cineclube Cinema é Poder! foi um projeto de ensino, pesquisa e extensão desenvolvido em parceria com o Grupo de Educação Multimídia - GEM/ UFRJ. Sua proposta era organizar acervos e realizar mostras bem como produçóes experimentais voltadas à abordagem do cinema independente $\mathrm{e}$ da afirmaçáo de identidades de grupos marginalizados. Os filmes debatidos no cineclube Cinema é Poder! para compor a mostra em 2019/1 foram: Now!, Santiago Alvarez (1965); O dia em que Dorival Encarou a Guarda, de Jorge Furtado (1986); Aluguel: O filme, de Lincoln Péricles (2015), Kbela, de Yasmim Thainá (2015), Nome de Batismo: Alice, de Tila Chitunda (2017). A estes filmes, acrescento outros do mesmo processo social também feitos como arranjos históricos: Cartão Vermelho, Laís Bodanski (1994), À meia-noite com Glauber Rocha, de Ivan Cardoso (1999), Porrada, Eduardo Coutinho (2000), Sauna, Marco Abujamra (2003), Electrodoméstica, Kleber Mendonça Filho (2005), Vida Maria, Márcio Ramos (2007), A peste de Janice, Rafael 
Figueiredo (2007), Hiato, Wladmir Seixas (2008), Fantasmas, André Novais (2010), Duplo, Júlia Rojas (2012). A lista ajuda a fazer um balanço do cinema independente no período.

O cinema nacional descrito parece ter aberto espaço para novas vozes, em parte se alimentando em grupos minoritários "empoderados" (que é quando um movimento se autodetermina), em parte interferindo na formação de uma nova subjetividade. Se tomarmos como referência os filmes $O$ dia em que Dorival encarou a guarda, de Jorge Furtado (1986), e Kbela, de Yasmin Thainá (2015), veremos perspectivas bastante diferentes sobre a liberdade do negro no Brasil. O primeiro amplifica a figura heroica do sujeito que deve se libertar e, apesar da força que aparenta ter, mesmo impotente, exercita a razáo e a retórica para vencer. O segundo desvincula o heroísmo do sujeito mas sublima o sofrimento da raça identificada com uma cultura forte. Os dois ilustram dois momentos do cinema nacional.

\section{O dia em que Dorival encarou a guarda}

"Milico e merda pra mim é a mesma coisa", diz o prisioneiro Dorival recursivamente ao longo da fita como último recurso de sua estratégia para conseguir manter a própria dignidade. Em um cárcere em alguma cidade grande brasileira em 1986, o preso experimenta a fórmula com toda a hierarquia do presídio (do recruta ao tenente) até satisfazer sua necessidade: tomar uma ducha para aliviar o calor infernal da solitária, onde está trancafiado há dez dias. Porém, só consegue seu intento depois de uma surra que o deixa todo ensanguentado, "para aprender a respeitar a autoridade", segundo às ordens do tenente. Este contudo cede somente após ser desmoralizado pela dura verdade que lhe cospe à cara Dorival: "vocês são todos uns pau-mandados, não sabem que quem deu a ordem para que eu não tomasse banho foi o carcereiro, que não vai com a minha cara."

Dorival é negro, "um negão desse tamanho, parece um king kong", na descrição do recruta ao cabo, a quem se vê obrigado a chamar para conter o iminente escândalo do rebelado. Daí em diante, o detento galga toda a hierarquia do presídio. "Ele tem ordens para não tomar banho", diz o cabo ao invocar o sargento, que o corrige: "não: há ordens para que ele não tome banho", antes de seguir até a cela. "Se há ordens para que ele não tome banho de dia, entendo que ele também não pode de noite" julga e resolve o tenente, interpelado pelo frustrado sargento, um pouco antes de a desordem de Dorival atingir seu clímax. A balbúrdia se organiza como uma corrente, elo a elo, até fechar o ciclo com a chave que desmoraliza toda a patente, mas instiga a repressão ao insubordinado. Só ensanguentado é que ele poderá realizar seu objetivo. A ordem ilegítima do carcereiro é a chave para abrir a cela: não há 
outro argumento depois dessa informaçáo. Ordem e desordem alternam-se, deslocam-se no diálogo intenso do filme e definem, como gangorra, uma dinâmica provocativa coerente com imagens da cultura nacional.

Gangorra dialética entre as duas instâncias opostas é como Antonio Candido analisa o princípio estrutural do romance Memórias de um Sargento de Milícias, escrito por Manuel Antonio de Almeida no século XIX. Dialética da Malandragem é um ensaio que analisa como cada um dos personagens do romance circula entre o respeito e a transgressão natural às leis locais. Para o crítico, a estrutura da narrativa seria baseada na "intuiçáo da dinâmica social brasileira", um fenômeno chamado de "formalização ou redução estrutural dos dados externos" (CANDIDO, p. 28). Almeida teria intuído princípios constitutivos da sociedade. Associada a formas populares de tricksters, tal dialética recupera do ritmo social um realismo infuso. Trata-se de uma gangorra que permeia as relaçóes sociais no Brasil do seu tempo. "As pessoas fazem coisas que poderiam ser qualificadas como reprováveis, mas fazem também outras dignas de louvor, que as compensam." (op. cit., p. 40)

No campo jurídico, normas rígidas e impecavelmente formuladas, criando a aparência e a ilusão de uma ordem regular que não existe e que por isso mesmo constitui o alvo ideal. Em literatura, gosto acentuado pelos símbolos repressivos, que parecem domar a eclosão dos impulsos. (op. cit., p. 42)

No filme de Jorge Furtado, o trânsito entre a aparência da ordem e a vida social essencialmente desordenada formam um balanço necessário para a sobrevivência de todos os personagens. Mas o que está em jogo, evidentemente, é a dignidade de Dorival. O recruta obedece ao cabo, que é subordinado ao sargento, que deve respeitar as determinaçóes do tenente. $\mathrm{O}$ soldado raso sabe que responderá primeiro sobre qualquer movimento fora do normal no seu plantão, principalmente vindo de um "negão desse tamanho", um "king kong" tal como seu imaginário vê o dominado, influenciado pelo seu preconceito e pela cultura de massa. $\mathrm{O}$ cabo ironiza a ingenuidade do seu imediato, incomodado com a interrupção da leitura de uma revista de western, justo na cena em que o sheriff está na iminência de salvar a mocinha das garras do índio selvagem. Porém, ele se vê obrigado a reportar a situação ao sargento, também negro, e que está incomodado por perder no plantão o último ensaio da escola de samba, de onde com muita dificuldade tenta lhe falar sua namorada ao telefone. Frustrados na expectativa de conter Dorival, a todos só resta agora apelar ao tenente. Este, antes do veredito final, é obrigado a interromper o filme Casablanca, do qual assiste justamente a cena em que a tensão entre os nazistas e a resistência francesa, lógica da narrativa, se dilui na voz de Dooley Wilson cantando As time goes by em um bar na França 
ocupada durante a $2^{\text {a }}$ Guerra. A indústria cultural norte-americana alimenta o imaginário da força repressora brasileira projetando a imagem e o lugar do inimigo, além da crença sem fundamento em uma ordem redentora do tempo. O filme mostra que as tensóes só encontram alívio com uma descarga de violência para manter a ordem, justificada nas distintas instâncias da lei. Este é o ritmo da vida social. Dorival sabe disso, desde o início, e é aí que mora a sua estratégia.

O filme vive um processo histórico, em que se torna possível dizer: "milico e merda pra mim é a mesma coisa", mas também uma lógica da formação das relaçôes sociais no Brasil. Dorival é reprimido, negocia e se sai mais ou menos bem, pois deve pagar pela ousadia. Nesse balanço entre provocar e ceder é que ele satisfaz sua necessidade. Sua imagem é complacente e subversiva. No fim de um período de ditadura militar, em uma sociedade culturalmente autoritária (SCHWARCZ, 2019), com práticas de violência negociadas, Dorival mostra os limites da abertura celebrada em 1986. E, se no contexto já é possível falar como Dorival, como o cinema independente abordará o tema posteriormente? Antes de continuarmos com Dorival, seria interessante um breve balanço sobre este tipo de filme feito no Brasil entre 1986 e 2015 e que assumem um tom de denúncias sociais, sobre o racismo e o chauvinimo.

Curta-metragem na democracia brasileira:

O panorama oferecido pela lista abaixo é restrito e tem a proposta de traçar um balanço do período de 1986 a 2016 no que diz respeito à reivindicação de direitos sociais. Além disso, a lista dos filmes sugere também aspectos da transformação no âmbito da forma cinematográfica graças à renovação dos meios de produção e da linguagem com o advento das mídias digitais e da internet. Isso inclui popularização da tecnologia, acesso à formação e à cidadania e amplo espaço de compartilhamento de narrativas. A reação à esta mudança formal, como era de se esperar, orienta-se pelos ataques institucionais à cultura e ao conhecimento crítico (universidades, movimentos sociais etc), e pelas manifestaçóes de ódio fundamentado na fé e na convicção contra expressóes sensíveis e indagadoras. $\mathrm{O}$ acervo reunido neste artigo anuncia problemas colocados e que disputam a subjetividade no Brasil hoje. Parte dele foi usado na mostra construída com estudantes universitários para cinedebate em escolas do ciclo básico. A trama buscada nas análises e na seleção olha para o modo como as produçóes independentes abordaram a realidade no período de construção de perspectivas democráticas. Que formas realistas emergiram e como passaram a vincular novas subjetividades? 
Lista de filmes estudados para compor a mostra Cinema é Poder:

1 - O dia em que Dorival encarou a guarda, Jorge Furtado (14 min., 1986)

2 - lha das Flores, Jorge Furtado (13 min., 1989)

3 - Cartão Vermelho, Laís Bodanzky (14 min., 1994)

4 - À meia-noite com Glauber Rocha, Ivan Cardoso (35 min., 1999)

5 - Porrada, Eduardo Coutinho (6 min., 2000)

6 - A Sauna, Marco Abujamra (15 min., 2003)

7 - Electrodoméstica, Kleber Mendonça Filho (22 min., 2005)

8 - Vida Maria, Marcio Ramos (9 min., 2007)

9 - A peste de Janice, Rafael Figueiredo (15 min., 2007)

10 - Hiato, Vladimir Seixas (20 min., 2008)

11 - Fantasmas (11 min., 2010)

12 - Duplo, Juliana Rojas (25 min., 2012)

13 - Kbela, de Yasmin Thayná (21 min., 2015)

14 - Aluguel: o filme, Lincoln Péricles (16 min., 2015)

15 - Nome de Batismo: Alice, Tila Chitunda (25 min., 2017)

Os filmes organizam fragmentos e propóem subjetividades em ebulição nos últimos 30 anos no Brasil. É possível formar um juízo estético e político na análise de sua forma e transformação. É possível sistematizar um olhar sobre o cinema curto independente na democracia brasileira e indicar um caminho. É um caminho que ilumina fundamentos e identifica olhares naturalizados. Há no balanço um movimento de amplitude de visibilidade da crítica aos limites impostos pela cultura às liberdades individuais e às opressōes sociais, de gênero, de cor etc. Há experimentos formais que ganham espaço na disputa por imaginários com novas subjetividades em relação aos temas apontados. A dialética entre a ordem e a desordem, vista em $O$ dia em que Dorival encarou a guarda, delineia-se sob novos contornos, iluminando outras agências e superaçóes inéditas. Nos filmes curtos e de baixo orçamento analisados, os marginalizados superam sem negociar a própria pele, o próprio sangue, como faz Dorival. A lista delineia um contorno que vai da figuração novelística ao filme híbrido entre documentário e ficção. Se em Dorival o tom é episódico, em Kbela o tom é de plenitude, de ascese. Se a dimensão da ordem se estrutura com desordem numa rigidez aparente, em que a exceção é geralmente a regra na tragédia diária, no cinema nos anos 1980; em 2015 a força de superação é quase mitológica e a potência é parte de uma cosmogonia ancestral que emerge como sentido. ${ }^{1}$

1 Neste artigo, somente $\mathrm{O}$ dia em que Dorival encarou a guarda e Kbela seráo analisados, os demais filmes da lista serăo comentados em outros debates. 
Nos filmes acima relacionados, é possível identificar uma trajetória de positivação de ideias sobre a liberdade de ser e agir nas figuraçóes do cinema independente. Questionamentos legítimos em chaves negociadas, não sem práticas discursivas e físicas violentas. Porém, talvez sejam formas expressivas que se voltam contra formas sociais das quais se originam, buscando impulsionar transformaçóes sempre distantes. Dorival não faz qualquer concessão na forma. Há interesses em conflito de cor, raça, cultura e sobre a noção de liberdade. $\mathrm{O}$ filme sugere que ser livre é orbitar o poder de maneira inquestionável. $\mathrm{Na}$ confusão burocrática, a violência se disfarça nas relaçóes entre a ordem e a desordem da gangorra dialética que propôs Antonio Candido. Mas há outro emaranhado que disfarça o peso das aproximaçóes.

Fragmentos recortados por Jorge Furtado montam cenas em que se conectam formas de ver via cultura de massa. Todos os militares encarados por Dorival têm sua subjetividade explicada pela via pelos mecanismos ficcionais da indústria cultural. Cinema, literatura, música popular materiais vinculados à cultura de massa e seus instrumentos de ilusão e naturalização ideológica. O realismo de Jorge Furtado é associativo e ressignifica a cultura visual reificada. Seus filmes iniciais são organizaçóes animadas de materiais de arquivo com produçóes novas, buscando aproximar problemas nas sequências espaço-temporais, como poderá se ler mais adiante. A colagem era um recurso barato e muito expressivo, como demonstram os filmes O dia em que Dorival encarou a guarda e Ilha das Flores.

Assim, a visão autoritária e legalista dos soldados é configurada pelas narrativas mainstream. $\mathrm{O}$ barateamento dos custos de produção com a tecnologia digital e dos próprios equipamentos talvez tenha contribuído para o desaparecimento estético da colagem como recurso expressivo. Desde o início do século XIX, tem sido possível realizar produçóes externas e internas com qualidade visual e a baixo custo. No futebol, no shopping, na escola, na classe média, na cidade, na tradição, em todos os lugares possíveis da cultura, as câmeras passam a frequentar tensóes e a tecer impressóes. A diversidade de filmes independentes aborda o desejo de amadurecimento da sociedade frente a questôes sobre os direitos humanos. Algumas conquistas são celebradas, referidas como mudanças paradigmáticas, mas talvez cedo demais. Kbela é uma celebração linda, enérgica, pulsante, é uma performance plasticamente envolvente e redentora. A força da negritude se projeta como energia emergente. Trata-se de um filme bem composto tecnicamente, que náo usa materiais de arquivo e atualiza o debate sobre visibilidade e produção negras.

Yasmin Thayná afirma que seu filme contou com toda a equipe de produção constituída de pessoas negras (THAINÁ, 2016a). Não usar imagens de arquivo é um dos seus argumentos. Esta realização foi realmente possível 
com o barateamento dos custos de produção, o acesso expandido à formação técnica e qualificada e ao fortalecimento do olhar e da voz dos direitos humanos. E estas novas coordenadas da produção audiovisual ofereceram no período novas imagens, um novo imaginário e novas imaginaçóes realistas no cinema. Para Ismail Xavier, por oposição ao "discurso como natureza" (preocupação com a fidelidade ao real e com a invisibilidade dos meios técnicos), o realismo busca captar a essência dos fenômenos e não apenas a aparência, visa a dinâmica social.

Num caso, é considerado real e concreto o imediatamente dado, o mundo visível e palpável; no outro caso, é real e concreto o processo, não dado à percepçáo direta, que define a ordem e a interelação entre os fenômenos, sendo realista a representação capaz de apreender as determinaçóes deste processo em suas manifestaçôes particulares (os fatos sociais) (XAVIER, 2008, p. 55)

Para Xavier, o cinema realista revela a sua própria condição de meio técnico, de linguagem, de ponto de vista sobre um tema que, visto de outros ângulos, sugere o real como narrativa estruturada e controlada. Cabe aos filmes realistas estimular a percepção dos mecanismos sociais e políticos em um dado processo histórico e social. "A arte será realista mais pelo significado produzido do que pela naturalidade de seus meios" ( $i d$.

O realismo cinematográfico, no período de 1985 a 2015, tem uma intensa transformação discursiva e técnica. Do ponto de vista técnico, o filme Cidade de Deus, de Fernando Meireles (2001) representa um verdadeiro evento, uma fronteira para um novo paradigma visual. "Literariedade do sangue", "dialética da agressão", "violência anestesiadora dos sentidos" são conceitos de José Carlos Félix sobre o realismo realizado no filme.

Em um contexto no qual a realidade é cruel e desumana e a sociedade é visivelmente desigual, o realismo surge como um potente meio de expressão, não apenas para descrever e denunciar injustiças, mas sobretudo para mobilizar grupos e indivíduos para a mudança. (FÉLIX, p. 171)

Porém, no caso de Cidade de Deus, segundo Félix, os artificialismos técnicos contribuiriam mais para uma espécie de ilusão naturalista. Como o diretor do filme iniciou sua carreira na publicidade e é um bem-sucedido publicitário no Brasil, Cidade de Deus usa todos os recursos técnicos modernos disponíveis para causar efeitos de continuidade espaço-temporal e efeitos de empatia com relação à violência estruturada nas comunidades carentes do Rio.

Longe de ser um veículo por meio do qual os oprimidos receberam voz, longe de ser um meio para a emancipação da comunidade das favelas, Cidade de Deus 
abriu um novo horizonte representacional para a indústria cultural brasileira. O resultado da cristalizaçáo desse novo gênero é que se tornou ainda mais difícil criar uma abordagem realmente nova para as comunidades das favelas, uma que se separaria efetivamente do esquema realista (ADORNO, 2008) que foi tão fortemente moldado na história recente do cinema. (FÉLIX, p. 182)

O naturalismo de Cidade de Deus serviria como um antídoto para a agressão cotidiana, na qual se disfarça em uma mesma atmosfera orgânica e natural. As imagens da violência em Cidade de Deus são extensão do mundo, tornando o discurso uma natureza, como conceitua Xavier. Cidade de Deus estabeleceu, portanto, um novo paradigma realista para a representação da violência urbana no Brasil. Um paradigma marcado pela insistência na violência como tema e, sobretudo, como forma técnica apurada. Seja para reforçar determinismos ou para negar estereótipos e classificaçóes, desenvolveu-se um novo imaginário cinematográfico com marca na violência e na luta social pela resistência e emancipação.

Este imaginário, entretanto, passou a ser questionado atualmente. Em $O$ Estado pós-democrático, Rubens Casara argumenta que a razão neoliberal tem aumentado seu campo de poder, impondo uma vinculaçáo indissociável entre economia e política, suprimindo os direitos e garantias individuais, eliminando os sujeitos indesejados e transformando tudo e todos em mercadorias (CASARA, 2017). O que caracterizaria a pós-democracia, segundo o autor, seria o fim dos limites ao exercício do poder, tornando a "democracia um mero simulacro, elemento discursivo apaziguador". Com o golpe de 2016, que impôs uma derrota ao projeto de expansão dos direitos com a deposição da primeira mulher a presidir o Brasil, institucionalizouse o Projeto Ponte Para o Futuro: redução da presença do Estado a simples mediador das negociaçóes em um livre mercado geral. A ação de regulação do Estado, todavia, seria estabelecida por conveniência e com ingerência contra tudo o que ofereça riscos a este projeto de modernização. O controle sobre a Ancine pelo governo atual, por exemplo, tem estabelecido "filtros" ao financiamento de filmes com produçóes independentes. Assim, os curtas apresentados nesta pesquisa tentam traçar um perfil do imaginário emergente no período em que foi possível disputar a subjetividade no cinema no Brasil, um momento que oferecia um horizonte mais democrático e inclusivo. À luz da teoria da história e da memória em Walter Benjamin (BENJAMIN, 1940 , p. 222), a questão que se coloca é: como pensar essas imagens do passado recente na disputa sobre o imaginário e a subjetividade no Brasil atual? Como tratar a imaginação acumulada e torná-la arma na luta social pela forma da resistência no cinema independente? A resposta talvez comece pela compreensáo do purismo no discurso em Kbela, via fluidez da forma com 
artifícios técnicos, mesmo que para afirmar a necessidade da visibilidade, do acolhimento e, sobretudo, da produção audiovisual negra.

\section{Um passo atrás}

Kbela, Yasmim Thainá (22 min., 2015), é um filme ou uma performance? se questiona um estudante em uma projeção do cineclube que deu origem a este artigo. Cinco mulheres vivenciam um processo de transfiguração que sugere sobretudo uma intensidade sensorial para elas e para os telespectadores. A estrutura do filme, contudo, conduz um movimento que vai do som metálico do sax do jazz à percussão do jongo. Os traços e a energia afirmam a força e a potência da identidade feminina afrodescendente. No ritmo inicial, bocas na tela proclamam expressóes racistas relacionadas ao cabelo e à cor ("cabelo duro", "pixaim", "macaco"). As palavras assumem açóes e gestos deslocados do sentido usual, tornando-se temas para a mudança provocada pela narrativa do filme através de diferentes quadros sucessivos. Estas imagens vistas na contramão são pura intensidade experimentada dramatúrgica, poética e criticamente. Desde vibraçóes que traduzem a crise com a autoimagem, projetada no desconforto com o cabelo, até a aceitação e o respeito, Kbela dá forma ao afeto, dá imagem ao olhar que identifica potências, tal como sugerem a sinopse e alguns frames do filme:

Um olhar sensível sobre a experiência do racismo vivido cotidianamente por mulheres negras. A descoberta de uma força ancestral que emerge de seus cabelos crespos transcendendo o embranquecimento. Um exercício subjetivo de autorepresentaçáo e empoderamento. (Canal Kbela no Youtube)

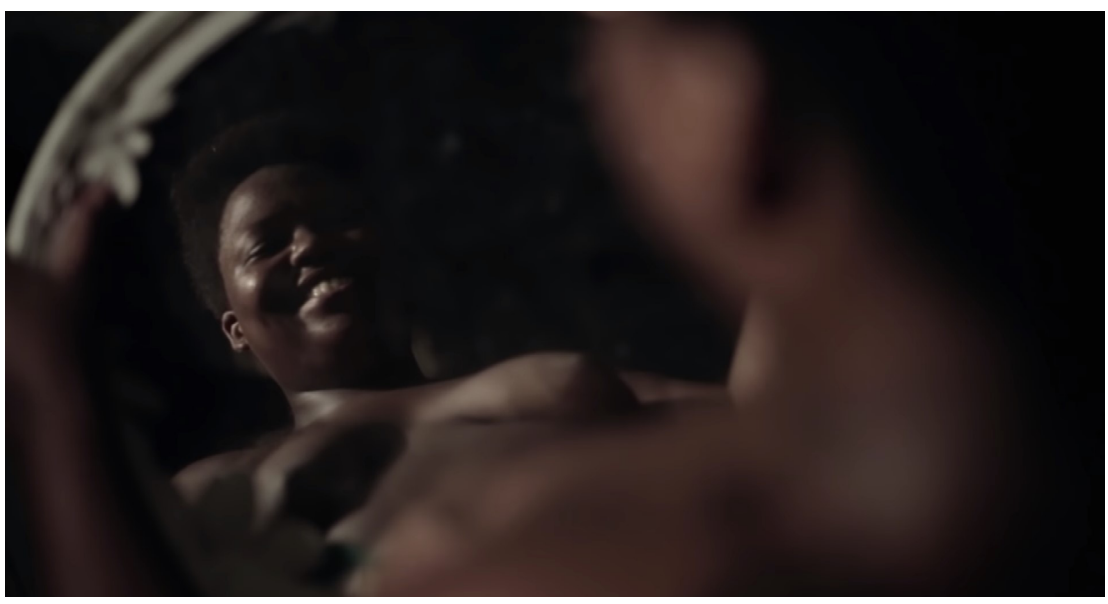

Figura 1 - Kbela 12'48"

Fonte: <http://encurtador.com.br/nJUZ1> 
Cobranças sobre a visibilidade e a agência de sujeitos emergentes tradicionalmente apagados nas produçóes audiovisuais ganharam a pauta, em especial nos filmes independentes nos últimos anos. Yasmin Thainá, diretora de um dos filmes estudados produzido em 2015 comenta em uma entrevista para o canal Diálogos Ausentes, do Itaú Cultural, sobre a fundação de uma plataforma dedicada a divulgar trabalhos com temática e produção negra. A Afroflix, segundo Thayná, "surgiu exatamente neste contexto (...) como forma de mapear e organizar produçóes feitas por pessoas negras: dirigidas, escritas, protagonizadas ou produzidas por pessoas negras." (THAINÁ, 2016c). Em outro vídeo, intitulado "Hackeando a narrativa, porque não sou obrigada” (THAINÁ, 2016b), ela acrescenta a perspectiva de novas narrativas e subjetividades forjadas na e pela periferia, se referindo diretamente à baixada fluminense, onde mora e produz.

Como resultado da análise imanente de um conjunto de filmes sobre o tema nos diferentes grupos de trabalho constituídos, organizou-se uma reflexáo sobre o imaginário no período de construção de uma ótica sobre a democracia audiovisual. Uma espécie de balanço do cinema independente no Brasil entre 1986 e 2016 no qual se percebe o lugar do negro, das mulheres, dos trabalhadores, dos pobres assumindo um estatuto tensionado. $O$ dia em que Dorival encarou a guarda, de Jorge Furtado (1986), para dar um exemplo, narra a estratégia e perspicácia de um detento negro para driblar a burocracia prisional e satisfazer uma necessidade básica: tomar uma ducha, depois de dez dias preso na solitária. Algo sistematicamente negado pela guarda em uma ordem que ninguém na hierarquia local conhece a origem. Kbela, Yasmin Thainá (2015), por outro lado, é um filme de uma mulher negra e de origem humilde que apresenta um ritual em que cinco mulheres exorcizam o preconceito racial acumulado contra elas em uma espécie de ascese que envolve raça, cultura e identidade a partir da aceitação do cabelo negro. Entre os dois filmes, um de 1986 e outro de 2015, é possível identificar uma trajetória de positivação de ideias sobre a liberdade de ser e agir no cinema independente. Este imaginário, entretanto, passou a ser questionado atualmente.

Em O Estado pós-democrático, Rubens Casara argumenta que a razão neoliberal tem aumentado seu campo de poder, impondo uma vinculaçáo indissociável entre economia e política, suprimindo os direitos e garantias individuais, eliminando os sujeitos indesejados e subjetividade que incomodam (CASARA, 2016). Assim, o panorama debatido nesta pesquisa traçou um perfil do imaginário emergente no período em que foi possível disputar a subjetividade e o imaginário cinematográfico no Brasil, um momento que oferecia um horizonte mais democrático.

O filme foi lançado em setembro de 2015, mesmo mês em que Dilme Roussef foi destituída "em nome de Deus e da família brasileira”. Dilma 
foi derrubada do poder por se opor ao Projeto Ponte para o Futuro, que é uma reelaboraçáo das estratégias do capital financeiro para se perpetuar via metamorfoses na ideologia liberal e do estado democrático de direito. Ponte para o Futuro é a configuraçáo do estado para o livre-mercado absoluto, onde empreendedorismo e inovação social são as novas senhas para abrir todas as portas, a começar pelas instituiçóes do próprio estado. Na razão neoliberal da pós-democracia, segundo Rubens Casara, o estado é monetarista em todas as suas iniciativas, políticas e em todo os seus poderes, "os bens, as pessoas, os princípios e as regras passaram a ser valorizados apenas na condição de mercadoria" (CASARA, 2017, p. 40). Com o esvaziamento da democracia participativa e o fim dos limites ao exercício do poder a um grupo corporativo, os direitos, as leis e a justiça estão a serviço de interesses privados daqueles consumidores que estão autorizados a usufruí-los.

No caso do Brasil, onde ordem e desordem dialetizam-se, segundo Antonio Candido, para responder a estímulos do capital externo, a pósdemocracia legitima a essência autoritária da cultura, superando a ideologia, na verdade um verniz, da cordialidade. Duas práticas coloniais: a violência familiar (com desfaçatez) e o respeito aos interesses estrangeiros (com gratidão) dáo o tom do projeto de progresso apresentado como Ponte para o Futuro. Dilma foi tirada do poder por ser mulher, por ser entendida como inflexível por aqueles que a tentaram comprometer com prejuízo para a sua imagem e também por ter posição progressista (apesar das contradiçôes de um governo de coalizão). Dilma foi deposta por sair da gangorra na qual a cultura encontra sua dinâmica, de acordo com Antonio Candido. É muito simbólico que um filme como Kbela, conceituado em torno da compreensão e transformação da subjetividade, seja apresentado no mesmo mês em que foi deposta a presidente que criou o Ministério da Mulher e dos Direitos Humanos. É simbólico, inclusive, porque o argumento do golpe buscou identificá-la com a intransigência. $\mathrm{O}$ filme aponta para outro sentido, não que deva ser o espelho da realidade, mas é a forma que se constrói como estratégia de transfiguração do próprio real. A premissa da sublimação da violência da cultura afirmando a subjetividade negra emerge das novas condições do estado, mas esbarra na reação social no país. As elites nacionais não suportam ver os negros representados longe das atividades servis nem as mulheres em posição superior. Aí talvez é que se encontre a negação da presidenta, da visibilidade proposta e, agora, de qualquer projeto cinematográfico que estimule uma tal subjetividade.

Na pós-democracia, a liberdade intocável é apenas a que garante a propriedade privada, a concentraçáo dos meios de comunicação de massa, a fabricaçấo de 'próteses de pensamento' - televisores, computadores, smatphones etc. - 
capazes de substituir cidadãos por consumidores acríticos, acumulação de bens, os interesses das grandes corporaçóes e a circulação do capital financeiro. (CASARA, 2017, p. 30)

Um acordo entre influxos externos e pragmatismo cultural locais, numa acomodação violenta e autoritária, como sugere Lilian Schwacrz no livro Sobre o autoritarismo (SCHWARCZ, 2019), em que a autora analisa diferentes disfarces do tema e suas renovaçóes na mitologia nacional. Sempre que se vêem ameaçados os interesses de classe no Brasil, surge uma nova ponte para o futuro, projetando práticas tradicionais sob nova roupagem e mantendo o estado de coisas inviolável. Kbela é um filme que depura uma acumulação democrática na ingenuidade da compreensão performada. É esteticamente muito bonito e delicado, é também muito provocativo pelo modo como enfrenta a violência de algumas expressóes que busca desmontar. Mas é um filme que, no seu inocente e justo desejo, nos oferece uma imagem de despedida. Tecnicamente, é refém do realismo de Cidade de Deus, pois o tom deslumbrado com a possibilidade técnica controlada faz desse curta uma ascese e uma contradição.

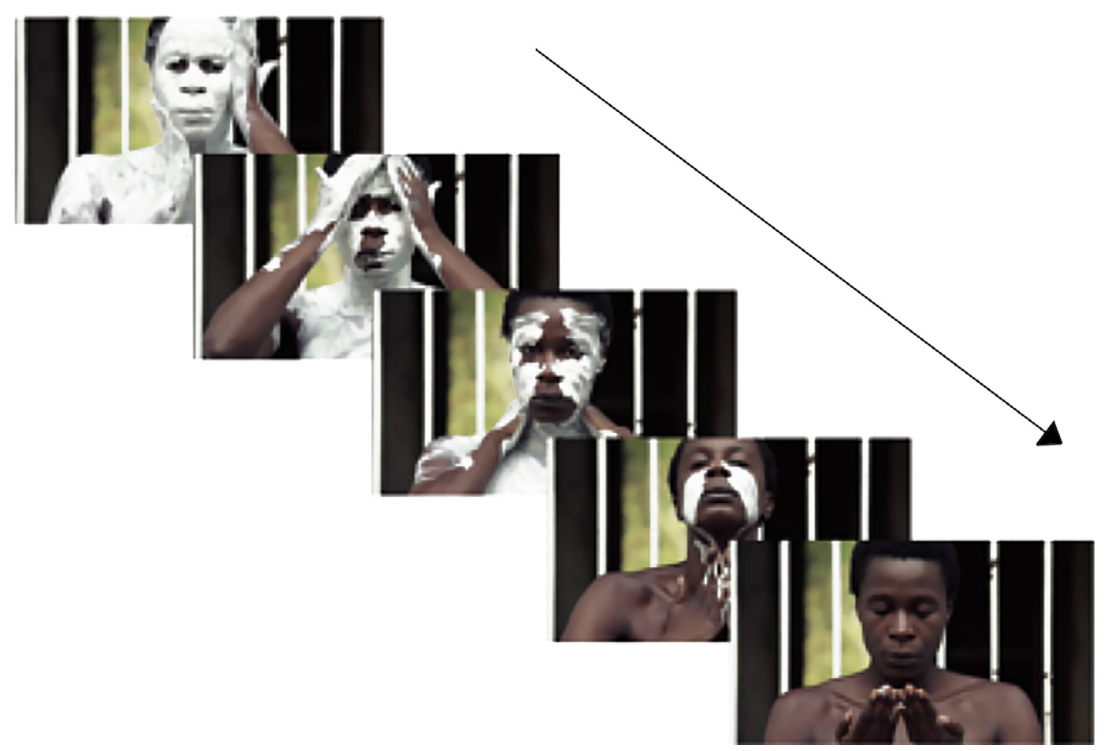

Figura 2 - Kbela 4'39"'-5'50"

Fonte: <http://encurtador.com.br/nJUZ1> 
Na sequência acima ilustrada, a purificação é um "desclareamento" tecnicamente produzido. O elogio da técnica é explicitamente disfarçado na busca da pureza espiritual e cultural. Thainá não quer ressignificar as imagens do passado, ela quer criar novas imagens, novos imaginários e novas imaginaçóes. O filme fica preso, entretanto, aos paradigmas comerciais que nega. $\mathrm{O}$ discurso se perspectiva contra qualquer violência, buscando algum tipo de purificação, mas acaba reafirmando pelo uso de recursos técnicos ilusionistas a supremacia violenta da tecnologia de controle social. A tecnologia como neutralidade e purificação é uma ideologia do mundo capitalista interessada em disfarçar as marcas do trabalho.

Kbela é sensível, é uma performance como foi sugerido pelo estudante Vinícius Novais no cinedebate no qual este artigo teve sua origem, é um filme que instiga o ser e o fazer em novas matizes culturais. De $O$ dia em que Dorival encarou a guarda até Kbela, o cinema nacional independente ensaia uma trajetória na qual diferentes sujeitos rompem o lugar em que estão presos, emergem de celas delimitadas por interesses escusos e obscuros e assumem a direção da performance e das intensidades provocadas. Dos questionamentos ao elogio da potência, a arte produz o caos e revela as artimanhas e contradições, mas também inspira a transfiguração íntima, a luta social e a criatividade coletiva. Dorival necessita atravessar as portas da senzala como um herói clássico, pela sua artimanha e coragem, ou enfrentar a própria dor indispensável e infalível, como um herói trágico. As personagens de Kbela estâo envolvidas e resolvidas a desconstruir alusóes, preconceitos e agressōes discursivas racistas e misóginas pela magia técnica. A linguagem é o meio em que se opera tal desconstrução.

É interessante que, dois anos depois, surja Nome de Batismo: Alice, um filme no qual a cineasta Tila Chitunda realiza uma viagem ao lugar e às memórias onde é possível dar sentido à sua identidade. Como se alicerça a ancestralidade de seu povo e quais os percalços de sua família? Talvez a resposta comece pela etimologia de nome que lhe atribuíram: Alice. Tila, cineasta negra de origem humilde, faz um cinema de redescoberta, de nascimento, ou renascimento, no limiar da democracia. Para Dorival e para as mulheres de Kbela, o mundo está configurado e é necessário desprogramá-lo. Nome de Batismo: Alice é de outra natureza, tem caráter narrativo e busca um percurso formativo. Tila é uma cineasta que viaja sozinha ao país de origem de sua família para encontrar os caminhos, as encruzilhadas e as contradiçóes estabelecidas na sua identidade atribuída e questionada.

Conclusão

"Kbela é um filme sobre ser mulher e tornar-se negra" (THAINA, 2017c). São quadros, espécie de instalaçôes audiovisuais, que performam 
situaçóes de preconceito e autonegação vividas cotidianamente por mulheres negras. Baseado em um conto escrito por Yasmin Thainá, Kbela apresenta uma narrativa lírica sobre a auto-descoberta e valorização do corpo negro. Assim como Nome de batismo: Alice, o filme de Thainá visa a superação da discriminação e a construção de uma nova subjetividade coletiva. Inspirado no livro Tornar-se negro: as vicissitudes da identidade do negro em ascensão, de Neusa Santos Souza, Kbela busca construir um discurso de afirmação da negritude como identidade autônoma na realidade concreta e contraditória, uma espécie de discurso histórico existencial: "Uma das formas de exercer a autonomia é possuir um discurso sobre si mesmo" (SOUZA, 1983, p. 18).

Essa perspectiva remete a Alma no Olho, de Zózimo Bulbul (1977), filme de que o próprio Kbela é uma releitura. No filme de Zózimo, closes sobre um fundo branco articulam as partes na sugestáo que produz uma identidade renovada. Um homem negro experimenta sintetizar com imagens e sem fala a história de escravização até a libertação plena dos negros no Brasil. Ao som de Kulu Sé Mama, John Coltrane (1965), Zózimo dirige, atua e monta Alma no olho, associando a transformação ao trabalho visto na sua dimensão histórica. Arrebentar as correntes da servidão é uma imagem histórica no sentido de que é uma ruptura com um estado de coisas e, também, porque pode ser compreendida desta maneira. O gesto de libertaçáo da imagem do trabalhador negro estimula o imaginário sobre um corpo livre porque há uma alma livre. Os olhos conectariam as duas instâncias permitindo imaginaçôes. O fundo infinito do filme é branco, os gestos do sujeito focado, no entanto, expressam os sistemas e atividades da dinâmica social e econômica em que está preso e a sua busca pela liberdade. O sujeito que emerge em Alma no Olho constrói sua liberdade também tecnicamente, pois é na montagem que se juntam os fragmentos de um ser integral e livre. Contudo, o foco é na técnica como recurso expressivo de coordenadas histórico-sociais não como natureza discursiva, como chama atençáo Ismail Xavier ao comparar naturalismo e realismo (XAVIER, 2008, p. 55).

Kbela, no entanto, assume a aparência gráfica da fotografia e a expressividade da montagem como recursos para uma experiência sensorial e sensível de acolhimento e autodescoberta. O que está em jogo é a construçáo de um discurso sobre si mesmo, como afirma a autora em um texto que vincula a sua obra à de Zózimo e identifica suas origens.

Assim como John Coltrane, uma outra intelectual, mulher negra, que consegue dialogar diretamente com o filme de Zózimo é a escritora e psicanalista Neusa Santos Souza, autora do livro "Tornar-se negro - as vicissitudes da identidade do negro em ascensão social”. (THAINÁ, 2017c) 
$\mathrm{O}$ artigo Ele nos ensina a ter a alma no olho, escrito por Thainá sobre o filme de Bulbul confirma a sua vinculação estética e crítica. O filme de Zózimo busca a superação histórica como correlato da superação de formas de opressão nas relações de trabalho. É a história de um sujeito trabalhador bem mais que a de um corpo que trabalha. Kbela, entretanto, demonstra que a expressão corporal contém os gestos de autonomia que visa produzir em todos, especialmente nas mulheres negras. Talvez as condiçóes objetivas para se pensar o que é libertação tenham mudado entre 1977 e 2015. Talvez a realidade histórica tenha deixado precocemente de importar mais que a perspectiva das potências individuais. Certamente é o momento de o cinema nacional aproveitar as facilidades da produçáo e do acesso e estimular canais coletivos de produção independente. Porém, sem uma perspectivação histórica da realidade concreta, um filme tende somente ao ilusionismo que encanta e nunca desencanta. É preciso realizar cinema como espaço politécnico, colaborativo e coletivo para reciclagem histórica com resignificação social e cultural. É preciso ter a alma no olho para narrar imagens, provocar imaginários e encorajar imaginações. É preciso fazer cinema independente e crítico da sociedade e da economia política, é preciso filmar a superexploraçáo do trabalho em ampla escala através da uberização econômica articuladas com a diminuição do estado na vida pública e social, comprometendo direitos civis e individuais. E, a partir de tudo isso, é urgente criar discursos autônomos sobre a identidade livre.

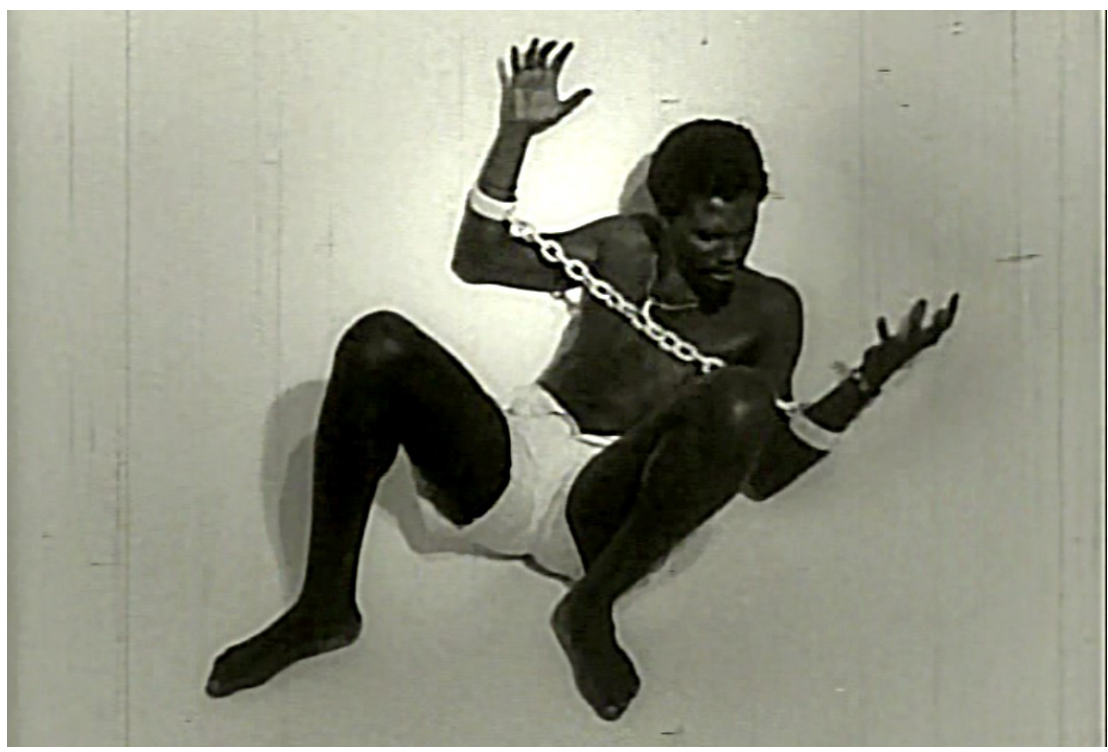

Figure 3 - Alma no olho, 6'48"

Fonte: <http://encurtador.com.br/nJUZ1> 
Pensar um cinema crítico é também fazê-lo com as próprias mãos. Um cinema realizado em tais condiçóes pode ser um pensamento que tira de si a matéria desejada para a transformação que visa ilustrar. $O$ dia em que Dorival encarou a guarda, Kbela, Nome de batismo Alice, Alma no olho são filmes que representam o corpo negro em condiçóes de enfrentamento e descoberta. Para o psicanalista norte-americano Richard Sennett, "fazer é pensar (...) o pensamento e o sentimento estáo contidos no processo do fazer" (SENNETT, p. 17). A ideia é defendida no livro O Artífice, no qual duas teses impulsionam o debate: "todas as habilidades, até mesmo as mais abstratas, têm início como práticas corporais" e "o entendimento técnico se desenvolve através da força da imaginaçáo" (SENNETT, p. 201-202). Para o teórico, a primeira tese está associada a trabalhos manuais, a segunda está ligada à linguagem. Uma e outra se completam no ato de fazer que pressupóe um imaginar prévio e uma conclusão posterior ao seu processo. Os filmes comentados neste artigo são feitos, pensados e sentidos em seus processos como intensidades críticas e sensíveis iniciadas no corpo mesmo da ação e do ser novo almejado.

Este artigo teve origem em um cineclube com estudantes secundaristas e da Faculdade de Letras da Universidade Federal do Rio de Janeiro. O questionamento central da proposta foi em relaçáo às escolhas estéticas e políticas dos filmes ao abordarem o problema das visibilidades e da produção de baixo orçamento. Tal cineclube visou organizar uma mostra e visitar espaços formativos para debater cinema e luta social no Brasil, o foco descoberto no calor das discussóes é o mais difícil em terra marcada pela cicatriz da escravidão. A mostra Cinema é Poder! permitiu vislumbrar a construção de um conceito organizado como oficina de produção técnica e crítica de um imaginário. Trata-se de um imaginário elaborado para estimular a imaginação e a leitura autônoma de imagens do passado que permanecem, as quais se busca desautomatizar. A mostra visou promover novas formas de ler o realismo no cinema de hoje, formas de apreender a realidade em movimento.

Em públicos contingenciados pelas mídias mais populares da indústria cultural, o impacto de uma projeção em tela grande, com som distribuído espacialmente pela sala escura, pode ser muito estimulante. A mostra Cinema é Poder! Now! estimulou debates sobre visibilidade e invisibilidade, discriminação, violência estrutural, ordenamento urbano, território, identidade, cultura de massa, consumo, emancipação, realismo. Estas ideias foram debatidas coletivamente e sintetizadas neste artigo para a construçáo de sentido da experiência criativa, crítica e formativa da montagem de uma mostra sobre o cinema livre no Brasil democrático. Em "O realismo e a realidade do sangue", Felix et all expóe, em visão negativa, como um bom produto técnico e artístico pode instrumentalizar um olhar e um fazer no cinema realista. 
O realismo não é sinônimo para espontaneidade. Como a percepção já é desde sempre estruturada, o realismo não é inimigo da técnica e, uma vez que o cinema possui um potencial quase ilimitado para a montagem, poderia ser um veículo privilegiado para a mudança social. (FELIX, 2108, p. 172)

A realização do cinedebate permitiu testar esta mesma afirmação em chave invertida. Analisar uma tradição cinematográfica fora do eixo que visa encontrar um caminho de continuidade e visibilidade ajudou a extrair dos filmes "um potencial quase ilimitado para a montagem" e a "mudança social". As imagens são produto e ao mesmo tempo modelo para a realidade. A arte se constitui do e para o real. Nossa subjetividade inspira e é inspirada pelos desenhos do tempo, onde se tece nossa vida com pontos de vista no espaço. $\mathrm{O}$ cinema analisado parece dizer que é preciso gravar este tecido aéreo instantâneo para a posteridade e de um ângulo que interrompa seu ritmo naturalizado. A disputa política polarizada atualmente prepara combates em todas as frentes, inclusive e, sobretudo, na cultura, na arte, na linguagem. A força autoritária se impóe obscurantista.

Os filmes comentados têm em comum serem questionamentos e oferecerem, pela forma, ritmos e intensidades subjetivas de grande impacto. O cinema independente curto é feito com baixo orçamento e com poucos compromissos contratuais. Por isso, visto em perspectiva, este acervo ajuda a compreender um balanço da e na cultura na era de experimento de uma semiótica democrática de formas mais ou menos livres. Organizar uma curadoria com estudantes em processos formativos é criar sentidos novos para o seu trabalho e engajamento. Debater todos os filmes para chegar a uma seleção, à hierarquia e à mediação adequada foi um projeto de formação, pesquisa e extensão que envolveu estudantes universitários e secundaristas. O processo encarou emoçóes, contradiçóes e reflexóes importantes sobre a linha tênue entre ritmos sociais e culturais naturalizados e a resistência na composição de formas cinematográficas, suas invenções artísticas e concessóes técnicas, estéticas e críticas. 


\section{Referências}

ÁLVAREZ, Santiago. O Jornalismo Cinematográfico. In: LABAKI, Amir (Org). Verdade de cada um. São Paulo: Cosac \& Naify, 2015.

ALVES JR. Douglas Garcia. Visóes infernais do Brasil: negatividade e mímesis em Cronicamente Inviável, de Sérgio Bianchi. In: LOUREIRO, Robson (Org.). A Teoria Crítica vai ao Cinema. Vitória: Edufes, 2010.

BENJAMIN, Walter. Sobre o conceito de história. In: BENJAMIN, Walter. Magia e técnica, arte e politica. Trad. Sérgio Paulo Rouanet. 3a. ed. São Paulo: Brasiliense, 1987.

CANDIDO, Antonio. A dialética da malandragem. In: CANDIDO, Antonio. $O$ discurso e a cidade. 3a. ed. Sáo Paulo/Rio de Janeiro: Duas Cidades e Ouro Sobre Azul, 2004.

CASARA, Rubens. Do Estado Democrático de Direito o estado Pós-Democrático. In: O Estado pós-democrático - neo-obscurantismo e gestão dos indesejáveis. $2 \mathrm{a}$. ed. Rio de Janeiro: Civilização Brasileira, 2017. [Entrevista com a cineasta negra Yasmin Thainá do Afroflix] por Lia Hama. Programa TPM/UOL. Disponível em: $<<$ https://revistatrip.uol.com.br/tpm/entrevista-com-a-cineasta-negra-yasminthayna-do-afroflix $>>$. Acesso em: 13.01.2020.

FÉLIX, José Carlos et al. Realismo e realidade do sangue: Cidade de Deus 15 anos depois. In: LOUREIRO, Robson (Org.). A Teoria Crítica volta ao Cinema. Vitória: Edufes, 2018.

SCHWARCZ, Lilian. Sobre o autoritarismo brasileiro. São Paulo: Cia. das Letras, 2019.

SENNETT, Richard. O Artífice. Trad. Clóvis Marques. 2a. ed. Rio de Janeiro: Record, 2009.

SOUZA, Neuza Santos. Tornar-se negro ou as vicissitudes da identidade do negro brasileiro em ascensão social. Rio de Janeiro: Ediçôes Graal, 1983.

THAINÁ, Yasmin. Encontros de Cinema. Itaú Cultural, 2016a. Disponível em: $<$ https://www.youtube.com/watch?v=qpbolqVesK8>. Acesso em 08.12.19.

THAINÁ, Yasmin. Hackeando a narrativa porque eu não sou obrigada. TED, $2016 \mathrm{~b}$. Disponível em: <https://www.youtube.com/watch?v=qpbolqVesK8>. Acesso em 08.12.19.

THAINÁ, Yasmin. Ele nos ensina a ter a alma no olho. 2016c. Disponível em: <https:// www.nexojornal.com.br/colunistas/2017/Ele-nos-ensina-a-ter-alma-no-olho>. Acesso em 08.12.19.

XAVIER, Ismail. $O$ discurso cinematográfico - opacidade e transparência. 4a. ed. São Paulo, Paz e Terra, 2008. 


\section{Filmes}

ALMA no olho. Direção de Zózimo Bulbul. Rio de Janeiro: coletivo, 1974. Youtube, (11'), cor. Disponível em: <http://encurtador.com.br/nvyBL> Acesso em 09.12.19

ALUGUEL: o filme. Direção de Lincoln Péricles. Rio de Janeiro: independente, 2015. Youtube (16'), cor. Disponível em: <http://encurtador.com.br/enyAO> Acesso em 09.12.19

À MEIA-noite com Glauber Rocha. Direção de Ivan Cardoso, São Paulo: independente, 1999. Youtube (35'), cor. Disponível em: <http://encurtador.com.br/flvU9> Acesso em 09.12.19

A PESTE de Janice. Direção de Rafael Figueiredo. Salvador: Casa Nova Filmes,2007. Porta-Curtas (15'), cor. Disponível em: <http://encurtador.com.br/iPX23> Acesso em 09.12.19

A SAUNA. Direção de Marco Abujamra, Rio de Janeiro: independente, 2003. Porta-Curtas (15'), cor. Disponível em: <http://encurtador.com.br/alLPZ> Acesso em 09.12.19

CARTÃO VERMELHO. Direção de Lais Bodanzky, São Paulo: Buriti Filmes, 1994. Youtube (14'), cor. Disponível em: <http://encurtador.com.br/dAKW5> Acesso em 09.12.19

CIDADE de Deus. Direção de Fernando Meireles. Rio de Janeiro: O2 Filmes e Globo Filmes, 2002. Netflix, (130’), cor.

ELECTRODOMÉSTICA. Direção de Kléber Mendonça, Recife: Future Shorts, 2005. Youtube (22’), cor. Disponível em: <http://encurtador.com.br/brDM0> Acesso em 09.12.19

ILHA das Flores. Direção de Jorge Furtado, Porto Alegre: Casa de Cinema, 1989. Porta-Curtas (12'), cor. Disponível em: <http://encurtador.com.br/dxJLQ> Acesso em 09.12.19

KBELA. Direção de Yasmin Thayná. Rio de Janeiro: independente, 2015. Youtube, (21'), color. Disponível em: <http://encurtador.com.br/kpQR9> Acesso em 09.12 .19

NOME de batismo: Alice. Direção Tila Chitunda. Recife: independente, 2017. Porta-Curtas, (25'50"), cor. Disponível em: <http://encurtador.com.br/gowz3> Acesso em 09.12.19

NOW! Direção de Santiago Alvarez. La Havana: ICAIC, 1965. Youtube, (5’), P\&B. Disponível em: <http://encurtador.com.br/yzMVZ> Acesso em 09.12.19 
O DIA em que Dorival encarou a guarda. Direção de Jorge Furtado. Porto Alegre: Casa de Cinema, 1986. Youtube (14'), cor. Disponível em: <http://encurtador. com.br/jvBJ5> Acesso em 09.12.19

O DUPLO. Direção de Juliana Rojas. São Paulo: independente, 2012. Youtube (25’), cor. Disponível em: <http://encurtador.com.br/mINY0> Acesso em 09.12.19

FANTASMAS. Direção de André Novais de Oliveira. Minas Gerais: independente. Youtube (11'), cor. Disponível em: <http://encurtador.com.br/JLMQV> Acesso em 09.12.19

HIATO. Direção de Vladimir Seixas. Rio de Janeiro: Guma Filmes, 2007. Youtube (16'), cor. Disponível em: <http://encurtador.com.br/oLNRY> Acesso em 09.12.19

PORRADA. Direção de Eduardo Coutinho, Rio de Janeiro: Crisis Produtivas, 2000. Youtube (5'), cor. Disponível em: <http://encurtador.com.br/mzV56> Acesso em 09.12.19

VIDA Maria. Direção de Márcio Ramos, Fortaleza: independente, 2008. Youtube (9’), cor. Disponível em: <http://encurtador.com.br/ghixZ> Acesso em 09.12.19

Paulo Maia é professor colaborador do Mestrado Profissional em Tecnologias Sociais do Núcleo Interdisciplinar para o Desenvolvimento Social - NIDES/UFRJ. É bolsista PNPD/Capes como pesquisador na área de Literatura Comparada, cadeira que também leciona como pós-doutorando na UFRJ, sob a supervisão de Eleonora Ziller. Atualmente, faz a coordenação acadêmica do Grupo de Educação Multimídia - GEM, na mesma universidade, laboratório onde também realiza ensino, pesquisa e extensão.

E-mail: paulomacae@gmail.com 